\title{
Hand hygiene with hand sanitizer versus handwashing: what are the planetary health consequences?
}

\author{
Brett Duane ${ }^{1}$. Jessica Pilling ${ }^{2} \cdot$ Sophie Saget ${ }^{1} \cdot$ Paul Ashley $^{3} \cdot$ Allan R. Pinhas $^{4} \cdot$ Alexandra Lyne $^{3}$
}

Received: 1 July 2021 / Accepted: 24 January 2022 / Published online: 23 February 2022

(c) The Author(s) 2022

\begin{abstract}
In order to reduce the transmission of pathogens, and COVID-19, WHO and NHS England recommend hand washing (HW) and/or the use of hand sanitizer (HS). The planetary health consequences of these different methods of hand hygiene have not been quantified. A comparative life cycle assessment (LCA) was carried out to compare the environmental impact of the UK population practising increased levels of hand hygiene during the COVID-19 pandemic for 1 year. Washing hands with soap and water was compared to using hand sanitizer (both ethanol and isopropanol based sanitizers were studied). The isopropanol-based HS had the lowest environmental impact in 14 out of the 16 impact categories used in this study. For climate change, hand hygiene using isopropanol HS produced the equivalent of 1060 million $\mathrm{kg} \mathrm{CO}_{2}$, compared to 1460 million for ethanol HS, 2300 million for bar soap HW, and 4240 million for liquid soap HW. For both the ethanol and isopropanol HS, the active ingredient was the greatest overall contributing factor to the environmental impact $(83.24 \%$ and $68.68 \%$ respectively). For HW with liquid soap and bar soap, there were additional contributing factors other than the soap itself: for example tap water use (28.12\% and $48.68 \%$ respectively) and the laundering of a hand towel to dry the hands ( $10.17 \%$ and $17.92 \%$ respectively). All forms of hand hygiene have an environmental cost, and this needs to be weighed up against the health benefits of preventing disease transmission. When comparing hand sanitizers to handwashing with soap and water, this study found that using isopropanol based hand sanitizer is better for planetary health. However, no method of hand hygiene was ideal; isopropanol had a greater fossil fuel resource use than ethanol based hand sanitizer. More research is needed to find hand hygiene sources which do not diminish planetary health, and environmental impact is a consideration for public health campaigns around hand hygiene.
\end{abstract}

Keywords Hand gel $\cdot$ Hand sanitizer · Planetary health $\cdot$ Environment $\cdot$ Carbon footprint $\cdot$ Planet $\cdot$ Industrial ecology

\section{Introduction}

Hand hygiene is one of the most important ways of avoiding pathogen transmission. (WHO 2020a).

Responsible Editor: Philippe Loubet

Brett Duane

brettdu@tcd.ie

Jessica Pilling

jxp906@student.bham.ac.uk

Sophie Saget

sagets@tcd.ie

Paul Ashley

sagets@tcd.ie

Allan R. Pinhas

allan.pinhas@uc.edu

Alexandra Lyne

Alexandra.lyne@nhs.net
1 Department of Public Health, Trinity College Dublin, Lincoln Place, , Dublin, Ireland

2 Department of Physics, University of Birmingham, Edgbaston, Birmingham B15 2TT, UK

3 Department of Paediatric Dentistry, UCL Eastman Dental Institute, UCL, Gower Street, London WC1E 6BT, UK

4 Department of Chemistry, University of Cincinnati, Cincinnati, $\mathrm{OH}$, USA 
COVID-19, the disease caused by a new coronavirus called SARS-CoV-2, was first reported to the World Health Organisation (WHO) on December $31^{\text {st }} 2019$, originating in Wuhan, China. (WHO 2019) The disease was stated as a pandemic in 12 March 2020 (WHO 2020b). Currently (April 22nd, 2021), 141.8 million people have been infected, with 3.026 million deaths globally (ECDPC 2020).

To help prevent pathogen spread and in particular of Covid-19, the WHO recommends hand washing with soap and water (HW) or cleaning hands with alcohol hand sanitizer (HS) whenever hands are visibly dirty, as well as if hands are not visibly dirty. The WHO and Centre for Disease Control (CDC) both state that it is necessary to clean hands at key times with soap and water or HS with at least $60 \%$ alcohol. The WHO provides guidance for the contents of HS sanitizer based on ethanol or isopropanol (Centre for Disease Control Prevention 2020; WHO 2020c, d, e) The Coronavirus pandemic and subsequent public health recommendations have brought a shortage of HS all over the world (New York Times 2020).

The WHO has two recommended formulations for HS: either ethanol or isopropanol as the alcohol 'active ingredient', with glycerin as a moisturiser. The ethanol or isopropanol alcohol has been shown to inactivate SARS-COV-2 (Kratzel et al. 2020). Ethanol is produced as a bi-product of carbohydrate fermentation, whereas isopropanol alcohol (2-propanol) is manufactured by the indirect hydration of the fossil fuel propylene. (Yang 2007; Britannica 2020). Plain soap works by mechanical action to remove pathogens but also to inactivate enveloped viruses, such as the COVIDvirus, dissolving the oily surface membrane (Sickbert-Bennett et al. 2005). Soap is made from reacting oil with a strong alkali or caustic (Hamner 2020).

Planetary health is the health of human civilization and the state of the natural systems on which it depends (Whitmee et al. 2015). The overall planetary (and public) health impact of hand hygiene is as yet unquantified. There are different ways to measure both environmental sustainability and the consequential planetary health impact. One method is service level carbon footprinting; this accounts for the climate change impact by looking at greenhouse gas emissions and global warming potential. However, not only is this a resource intensive process, but climate change and global warming is a single measure of sustainability and does not account for impacts such as eutrophication of water supplies, resource scarcity, and reduction in biodiversity, to name a few.

A life cycle assessment (LCA) can also be used to consider the entire life cycle of a product from 'cradle to grave'. LCA data can be used to quantify multiple environmental impacts as well as other useful public health information such as Disability Adjusted Life Years (DALYs). DALYs consider both the time lost to premature death and reduced quality of life due to illness. (DALYs 2020).

Although LCAs have been used to compare different types of hand drying (Joseph et al. 2015), from our knowledge LCAs have not been used to compare the use of HS types compared with HW. The objectives of this study were to compare the environmental sustainability of the UK population using different methods of hand hygiene using ethanol and isopropanol HS vs using liquid and bar soap HW, in the context of the COVID-19 pandemic.

\section{Materials \& methods}

\section{Comparative LCA}

A comparative attributional LCA of 4 different hand hygiene techniques was undertaken at the Eastman Dental Hospital, London, in partnership with the Dublin Dental University Hospital (Trinity College Dublin, Ireland). The four hand hygiene techniques were:

1. Ethanol-based HS: individual disinfects hands with $0.4 \mathrm{ml}$ of hand sanitiser, made from WHO formulation I (WHO 2009)

2. Isopropanol-based HS: individual disinfects hands with $0.4 \mathrm{ml}$ of hand sanitiser, made from WHO formulation II (WHO 2009)

3. Liquid soap HW: individual washes hands with $0.75 \mathrm{ml}$ of liquid soap and 3.33L of tap water, drying hands with a laundered hand towel.

4. Bar soap HW: individual washes hands with $0.15 \mathrm{ml}$ of bar soap and 3.33L of tap water, drying hands with a laundered hand towel.

The functional unit was defined as the UK population practicing COVID-19-related hand hygiene for 1 year. This time period was chosen as it reflects the time that the COVID-19 pandemic is currently expected to be at least as prevalent. (Charumilind et al. 2020). The LCA methodology was applied in line with the ISO standards (ISO 2015) and PEF guidelines (European Commission Joint Research Centre 2018). The system boundaries are available in Fig. 1.

A life cycle inventory was created for each hand hygiene technique. Each technique was modelled as a generic product manufactured in the UK, not based upon a specific brand or product. The assumptions for each stage are detailed below. The life cycle inventory is available in Appendix B.

\section{Materials \& manufacture}

The components and manufacturing processes for hand sanitiser were based on the WHO hand hygiene guidelines (WHO, 2009). The weight of each constituent of the 


\section{A \\ Raw materials Manufacture \& packaging \\ Retail \\ Use \\ Disposal}
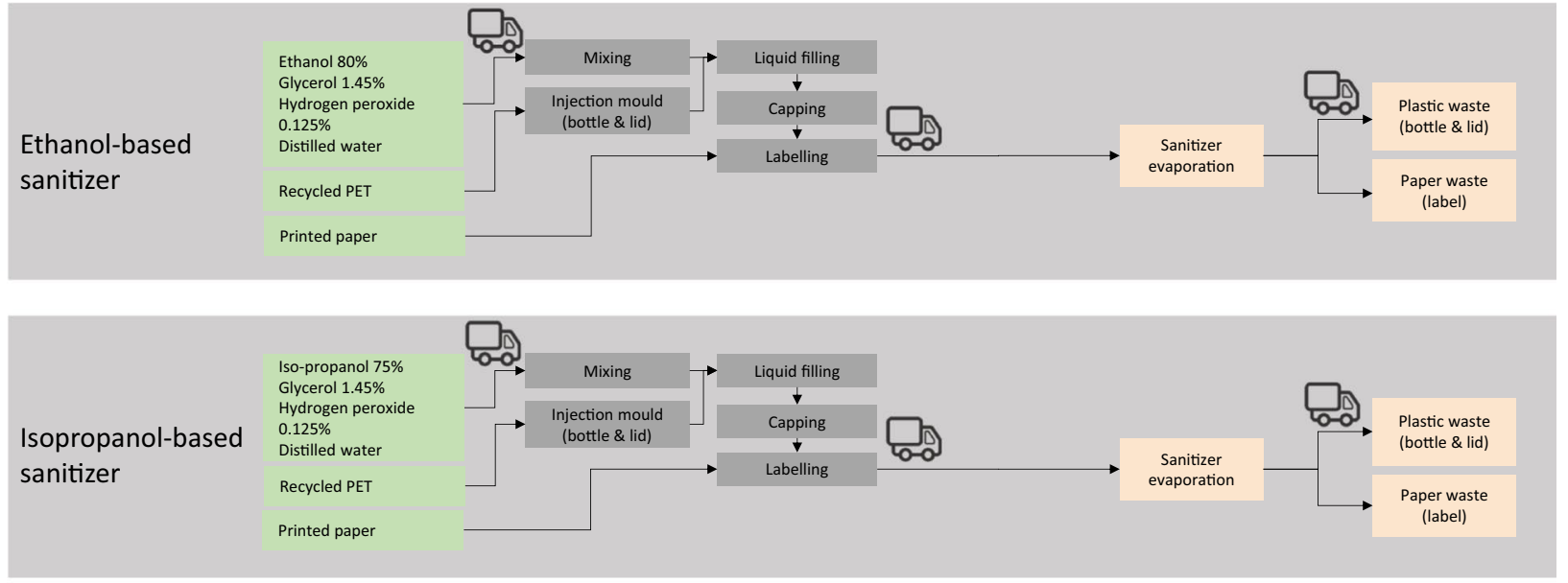

Key: $\quad$ Inputs
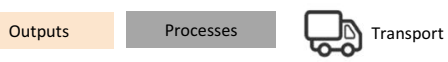

B Raw materials

Manufacture \& packaging

Retail

Use

Disposal
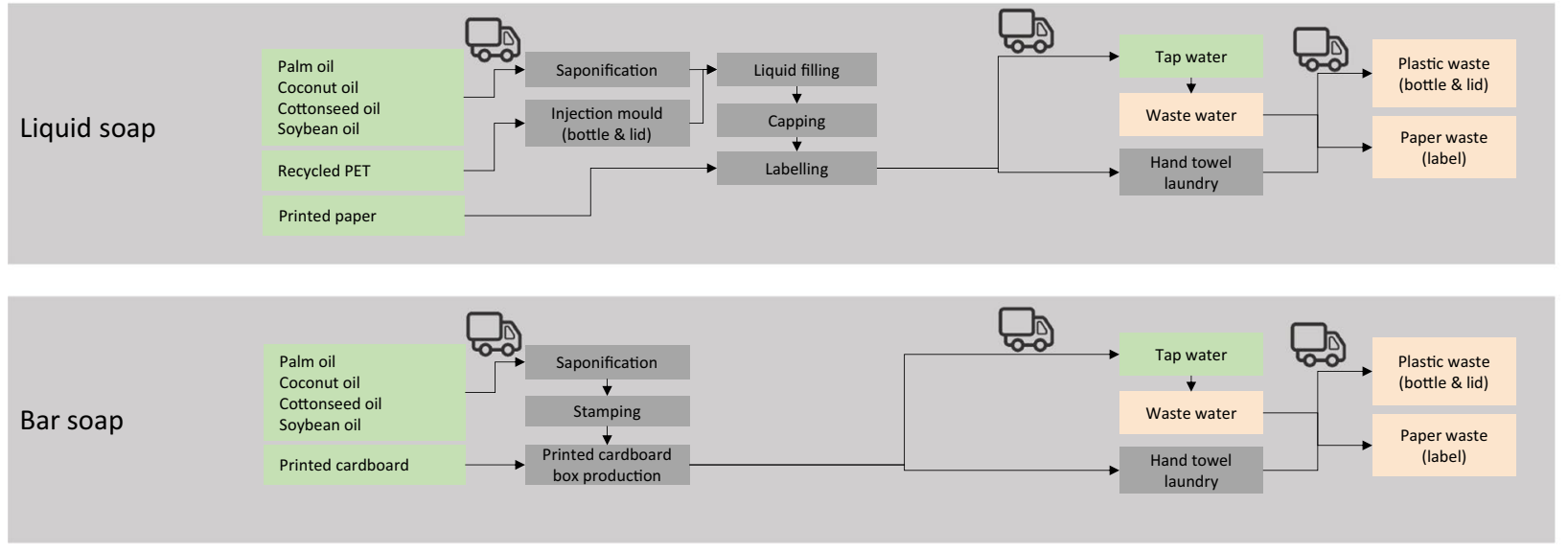

Key:

Fig. 1 A System Boundaries for hand sanitizer, B System boundaries for handwashing

sanitiser was based on the density and volume needed to produce $1 \mathrm{~L}$ of product. Fragrances and pigments were excluded from all products as they were not consistent product by product, and were assumed to be present in equal quantities across all types of products assessed. It was assumed that components for hand sanitiser were mixed in a pressure-protected mixing machine and immediately packaged in screw top bottles to prevent evaporation, as per WHO guidelines (WHO, 2009). It was assumed that all liquid soap and sanitizer products were packaged by machine assembly in $1 \mathrm{~L}$ cylindrical plastic bottles (made from recycled polyethylene terephthalate) with a plastic lid (polyethylene) and a printed paper label that wraps around the bottle. The weight of the bottle, lid, and label were based on a tear down of a sample 1L sanitizer bottle. The constituents of the liquid and bar soap were assumed to include palm oil, cottonseed oil, and soybean oil as per the Ecoinvent (2020) dataset for a basic soap. For bar soap, it was assumed that $90 \mathrm{~g}$ bars of soap were stamped and packaged in printed cardboard boxes only, based on a tear down of a sample bar of soap.

\section{Transport}

Assumptions for transport of the products from the factory to retailer, and then from retailer to consumer, were based on the PEF recommendations for modelling transport (European Commission Joint Research Centre 2018). This 
assumes the manufacturing location was $300 \mathrm{~km}$ from the UK retailer, i.e. a $600 \mathrm{~km}$ round via lorry (based on the weight of the transported products). The impact of retail processes themselves was excluded from the system boundaries of this LCA. The transport from the retailer to the consumer home was allocated transport was modelled following PEF guidelines (European Commission Joint Research Centre 2018).

\section{Consumer use}

Based on hand hygiene advice to control the transmission of COVID-19 (NHS England 2019; DOHSC 2020), it was assumed that each individual in the UK would practice hand hygiene for COVID-19 purposes an average of 15 times per day. This is based on the average individual leaving the house twice daily (for work and one other occasion), using the toilet 5 times, coughing or sneezing twice, and preparing meals. The functional unit in this study was the entire UK population, which was assumed to be $66,796,800$ individuals based on 2019 government data (Office for National Statistics 2020). The amount of sanitiser used per episode of hand hygiene was assumed to be $4 \mathrm{ml}$ based on Zingg et al. (2016)' The amount of soap used per episode of hand hygiene was deemed to be $0.35 \mathrm{~g}$ for the bar soap (McGill 2020 ) and $1.5 \mathrm{ml}$ for liquid soap (based on the average volume an individual receives from 1 pump of a soap dispenser, Richter 2016).

Hand hygiene with HS does not require water. For HW with liquid or bar soap, it was assumed an individual would use room temperature tap water for an average of $40 \mathrm{~s}$ (NHS, 2019) with a UK tap using $5 \mathrm{~L}$ of water per minute (DEFRA 2015a, b) (Table 1).

Hand hygiene with HS does not require drying the hands with a towel as the contents evaporate. For HW with liquid or bar soap, the drying of hands with a hand towel was included. It was assumed individuals would be practicing HW at home, and therefore using a pre-existing hand towel to thoroughly dry their hands. Therefore, the manufacture of the towel was excluded from the system boundaries, but the laundering of the hand towel was included. It was assumed that each household would share a $350 \mathrm{~g}$ hand towel (based on an average of 2.3 people per household in the UK) and would launder this hand towel every other day (Sturt 2015; Statistica 2021; Chilton 2004).

Table 1 Estimated consumer use per year per person

\begin{tabular}{lll}
\hline & Quantity per year per person & Water use \\
\hline Sanitiser & 21.91 & - \\
Liquid soap & 8.21 & 18,2501 \\
Bar soap & $1.9 \mathrm{~kg}$ & 18,2501 \\
\hline
\end{tabular}

\section{Disposal}

For the bottled products, it was assumed that individuals would dispose of the plastic bottle and lid in plastic recycling, and the paper label in paper recycling in the UK. For the bar soap, it was assumed the cardboard box of soap was recycled.

For the ethanol HS, the amount of ethanol absorbed through the skin is negligible, and the amount of ethanol inhaled by the user is only a couple of percent (Brewer and Streel 2020). Thus, almost all of the ethanol in normal use (approximately 98\%) is lost by evaporation into the air. Two percent of the ethanol was assumed to be excreted through the human body.

It is known that the ethanol in a hand rub sanitizer on a metal or glass plate at ambient temperature (approximately 21 degrees $C$ ) evaporates quite rapidly. The first-order halflife was found to be approximately $8 \mathrm{~min}$, which means that half of the amount present at any time will evaporate in the next 8 min (Pinhas 2010). Therefore, it is assumed, given the warmer skin temperature (approximately 35 degrees $\mathrm{C}$ ) and the thin film generated by rubbing of hands together, that almost all of the ethanol disappears by evaporation (the first-order half-life is estimated at less than $2 \mathrm{~min}$ ).

For the isopropanol HS, the boiling point isopropyl alcohol is 82 degrees $\mathrm{C}$ and its vapor pressure at 35 degrees $\mathrm{C}$ is $95 \mathrm{~mm} \mathrm{Hg}$ (NLM 2021). Unlike the measurements for ethanol in hand rub sanitizers, the kinetics of evaporation of isopropanol in hand rub sanitizers have not been measured. However, given these vapor pressure data, the rate of evaporation and the amount of evaporation at any time was assumed to be similar and the evaporation/metabolism in the human body was assumed to be the same. Glycerine and water were assumed to be absorbed by the human body and excreted through waste water.

\section{Data analysis}

Data from the life cycle inventory was modelled and analysed in OpenLCA (2020) v11, alongside the reference database Ecoinvent v3.7.1. Appendix A describes the different midpoint impact categories and LCIA methods used in this study, based on the PEF guidance (European Commission Joint Research Centre 2018). The results were normalised against average global per capita reference values in order to compare the relative significance of each impact category. A contribution analysis was performed for the following endpoint impact categories; human health, ecosystem damage, and resource use. For liquid soap HW, a sensitivity analysis was performed to vary the quantity of soap and water used per episode of handwashing and examine the effect of the variation on the LCIA results. DALYs were calculated for each product using ReCiPe 2016 (H) Endpoint. 


\section{Results}

\section{Life cycle impact assessment}

The results of the LCIA are shown in Table 2. The highlighted red cells represent the products with the highest impact in each category. HW with liquid soap and water had the greatest impact in 6 out of the 16 categories, followed by ethanol HS in 6 categories, and bar soap in 3 categories. Similarly, the highlighted green cells represent the products with the lowest impact in each category. Isopropanol HS had the lowest impact in 14 out of the 16 categories, followed by ethanol HS and bar soap (which had the lowest impact in fossil fuel use and photochemical ozone formation respectively).

\section{Normalised results and contribution analysis}

The normalised results compare the impact of using HS or HW against one global person's annual share of all emission and resource use in the world (the impact that the "average Joe" would be expected to make from living their daily lives for 1 year). Figure 2 presents the normalised results. An average person would use " 1 " per year in each category. Each impact category has a different normalisation factor, which is part of the LCIA methods. These factors are discussed in Appendix A.

As per PEF recommendations, the toxicity categories have been removed (European Commission Joint
Research Centre 2018). Photochemical ozone formation had the greatest normalised impact for both types of HS, equivalent to the annual contribution of 16 million people for ethanol HS and 3 million people for isopropanol HS. Freshwater eutrophication was the most significant impact category for both types of HW, equivalent to the annual contribution of 3.5 million people for the liquid soap and 1 million people for the bar soap.

A contribution analysis was carried out for each impact category. Figures 3, 4, 5, and 6 show the contributions for each type of hand hygiene to each endpoint impact category. For both types of HS, it was the ingredients to make the sanitizer that had the greatest contribution (83.46-91.04\% for ethanol HS, and 77.59-90.29\% for isopropanol HS). When broken down further into the individual ingredients, the active ingredient in the HS was the main contributor, and the remaining ingredients (glycerine, water, and hydrogen peroxide) did not contribute more than $13 \%$ in any category. The packaging (a plastic bottle and paper label) contributed $4.80-9.46 \%$ for the ethanol HS and 5.76-11.39\% for the isopropanol HS. For the liquid soap HW, the greatest contributor was the soap itself (46.04-75.92\%) followed by tap water use (14.11-38.51\%) and laundry for the hand towel $(8.25-12.32 \%)$. For the bar soap HW, the greatest contributor was the tap water (34.42-52.86\%) followed by the soap (22.88-47.99\%) and laundry for the hand towel (17.25-23.68\%). For both soaps, the packaging contributed no more than $1.5 \%$ in any category.

Table 2 LCIA results

\begin{tabular}{|c|c|c|c|c|c|}
\hline \multirow[t]{2}{*}{ Impact category } & \multicolumn{5}{|l|}{ LCIA results } \\
\hline & Units & $\begin{array}{l}\text { Sanitizer } 1 \\
\text { (Ethanol based) }\end{array}$ & $\begin{array}{l}\text { Sanitizer } 2 \text { (Iso- } \\
\text { propanol based) }\end{array}$ & Liquid Soap \& water & Bar Soap \& water \\
\hline Climate change (CC) & $\mathrm{kg} \mathrm{CO}_{2}$ eq & $1.46 \mathrm{E}+09$ & $1.06 \mathrm{E}+09$ & $4.24 \mathrm{E}+09$ & $2.30 \mathrm{E}+09$ \\
\hline Acidification (FTA) & $\mathrm{mol} \mathrm{H}+\mathrm{eq}$ & $1.94 \mathrm{E}+07$ & $4.47 \mathrm{E}+06$ & $1.85 \mathrm{E}+07$ & $9.38 \mathrm{E}+06$ \\
\hline Freshwater ecotoxicity (ECF) & $\mathrm{CTU}$ & $2.19 \mathrm{E}+10$ & $9.90 \mathrm{E}+08$ & $1.35 \mathrm{E}+10$ & $7.02 \mathrm{E}+09$ \\
\hline Freshwater eutrophication (EUF) & $\mathrm{kg} \mathrm{P}$ eq & $4.29 \mathrm{E}+05$ & $1.44 \mathrm{E}+05$ & $9.28 \mathrm{E}+06$ & $2.65 \mathrm{E}+06$ \\
\hline Marine eutrophication (EUM) & $\mathrm{kg} \mathrm{N} \mathrm{eq}$ & $1.01 \mathrm{E}+07$ & $9.94 \mathrm{E}+05$ & $1.54 \mathrm{E}+07$ & $5.62 \mathrm{E}+06$ \\
\hline Terrestrial eutrophication (EUT) & mol $\mathrm{N}$ eq & $7.84 \mathrm{E}+07$ & $8.23 \mathrm{E}+06$ & $5.89 \mathrm{E}+07$ & $2.72 \mathrm{E}+07$ \\
\hline Carcinogenic effects (CE) & CTUh & $6.99 \mathrm{E}+01$ & $1.60 \mathrm{E}+01$ & $2.61 \mathrm{E}+02$ & $3.07 \mathrm{E}+02$ \\
\hline Ionising radiation (IR) & $\mathrm{kg} \mathrm{U}^{235} \mathrm{eq}$ & $9.05 \mathrm{E}+07$ & $6.08 \mathrm{E}+07$ & $2.91 \mathrm{E}+08$ & $9.92 \mathrm{E}+07$ \\
\hline Non carcinogenic effects (NCE) & CTUh & $1.64 \mathrm{E}+03$ & $1.34 \mathrm{E}+02$ & $4.65 \mathrm{E}+02$ & $4.89 \mathrm{E}+02$ \\
\hline Ozone layer depletion (OD) & $\mathrm{kg} \mathrm{CFC}^{11} \mathrm{eq}$ & $1.66 \mathrm{E}+02$ & $6.48 \mathrm{E}+01$ & $2.68 \mathrm{E}+02$ & $1.71 \mathrm{E}+02$ \\
\hline Photochemical ozone creation (POF) & kg NMVOC eq & $6.43 \mathrm{E}+08$ & $1.39 \mathrm{E}+08$ & $1.15 \mathrm{E}+07$ & $6.82 \mathrm{E}+06$ \\
\hline Respiratory inorganics (RI) & Disease inc & $1.41 \mathrm{E}+02$ & $3.99 \mathrm{E}+01$ & $2.72 \mathrm{E}+02$ & $1.48 \mathrm{E}+02$ \\
\hline Water use (DW) & $\mathrm{m}^{3}$ water eq & $6.26 \mathrm{E}+09$ & $3.59 \mathrm{E}+08$ & $1.14 \mathrm{E}+10$ & $1.19 \mathrm{E}+10$ \\
\hline Fossil fuel use (FF) & MJ & $1.58 \mathrm{E}+10$ & $2.82 \mathrm{E}+10$ & $3.57 \mathrm{E}+10$ & $2.60 \mathrm{E}+10$ \\
\hline Land use (LU) & Points & $2.47 \mathrm{E}+11$ & $1.06 \mathrm{E}+10$ & $2.38 \mathrm{E}+11$ & $7.37 \mathrm{E}+10$ \\
\hline Mineral/ metal use (MM) & $\mathrm{kg} \mathrm{Sb}$ eq & $9.27 \mathrm{E}+03$ & $7.24 \mathrm{E}+03$ & $3.06 \mathrm{E}+04$ & $1.94 \mathrm{E}+04$ \\
\hline
\end{tabular}


Fig. 2 Normalised LCIA results for different types of hand hygiene
Fig. 3 Contribution analysis for ethanol-based HS
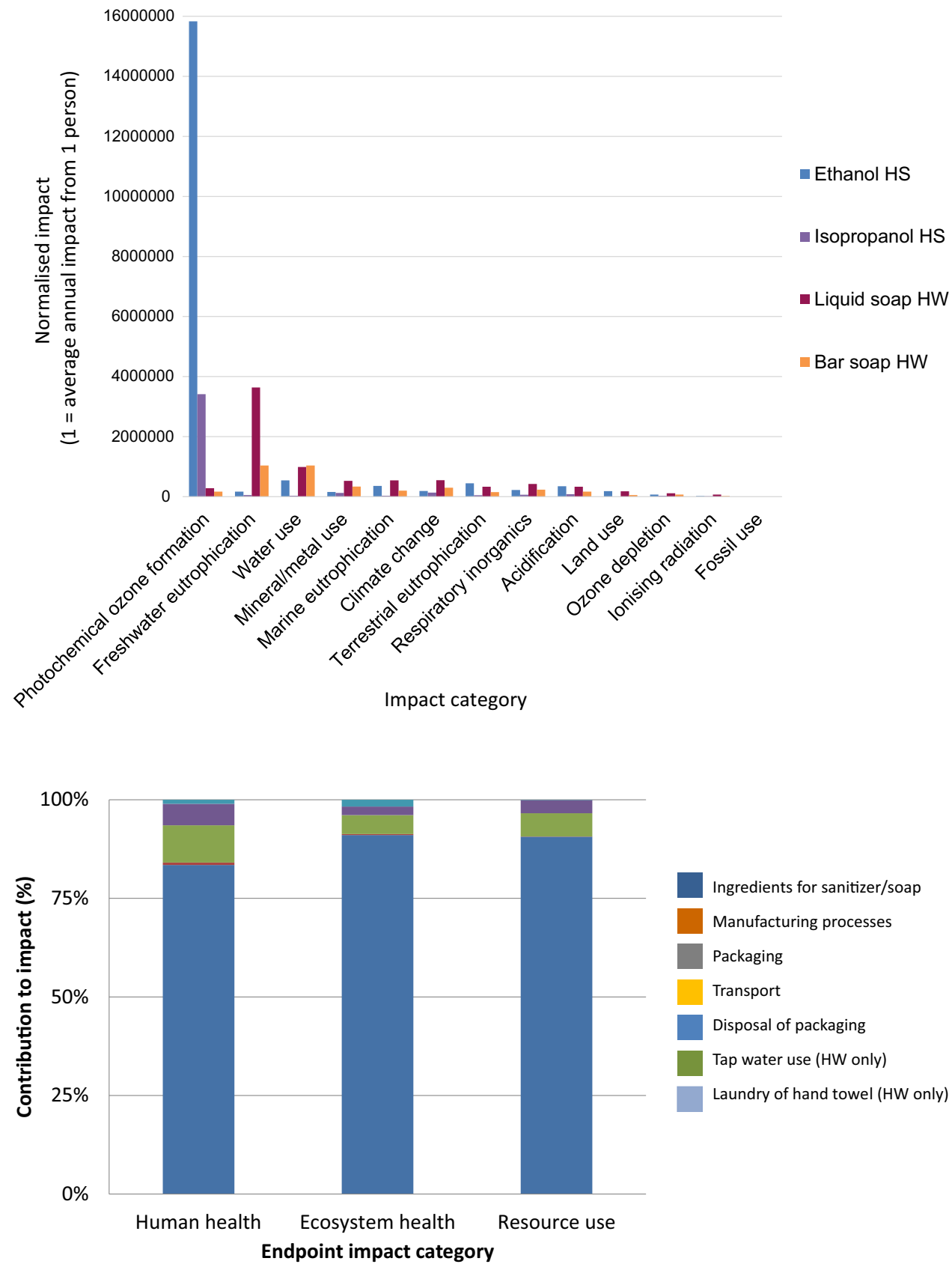

\section{Sensitivity analysis}

A sensitivity analysis for liquid soap HW was performed to examine the effect of increasing or decreasing the volume of liquid soap, as different brands will dispense different amounts of soap per 'pump'. The original assumption was that the pump would dispense $1.5 \mathrm{ml}$ of liquid soap. Halving the pump volume, to $0.75 \mathrm{ml}$, reduced the LCIA results by an average of $31 \%$ (range from $13 \%$ in carcinogenic effects to $47 \%$ in freshwater eutrophication). Similarly, doubling the pump volume, to $3 \mathrm{ml}$, increased the LCIA results by an average of $61 \%$ (range from $26 \%$ in carcinogenic effects to $94 \%$ in freshwater eutrophication).

Another sensitivity analysis for liquid soap HW was performed to examine the effect of increasing or decreasing the volume of water used to wash the hands. The original assumption was that $3.33 \mathrm{~L}$ of water were used per episode of handwashing (tap running for $40 \mathrm{~s}$ at $5 \mathrm{~L} / \mathrm{min}$ ). Halving the water use, to $1.67 \mathrm{~L}$, reduced the LCIA impact by an average of $86 \%$ (range from $66 \%$ in carcinogenic effects to $98 \%$ in land use); and doubling the water use, to $6.66 \mathrm{~L}$, increased the LCIA impact by an average of $28 \%$ (range from $3 \%$ in land use to $69 \%$ in carcinogenic effects). 
Fig. 4 Contribution analysis for isopropanol-based HS
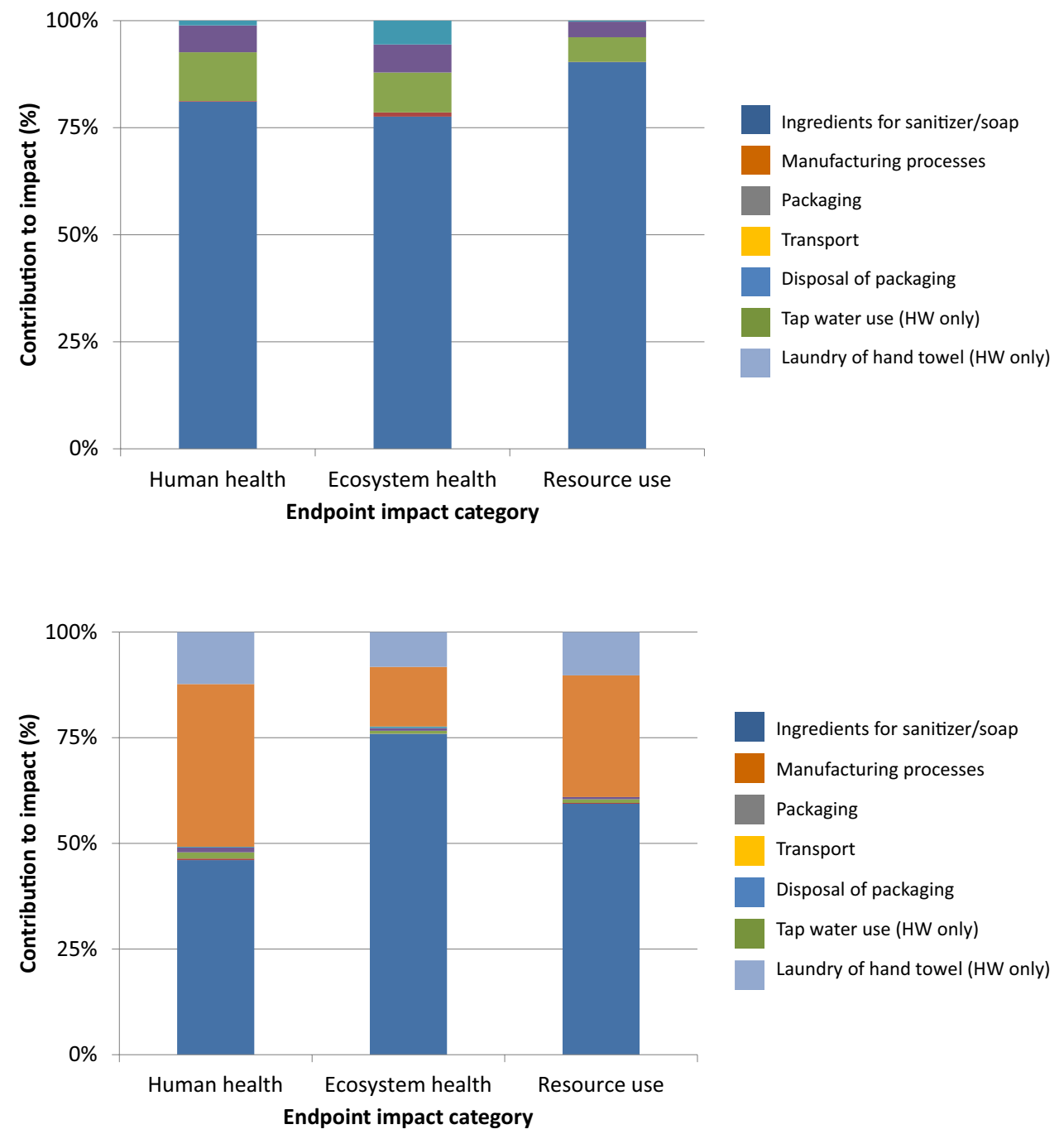

Ingredients for sanitizer/soap

Manufacturing processes

Packaging

Transport

Disposal of packaging

Tap water use (HW only)

Laundry of hand towel (HW only)
Fig. 6 Contribution analysis for bar soap HW

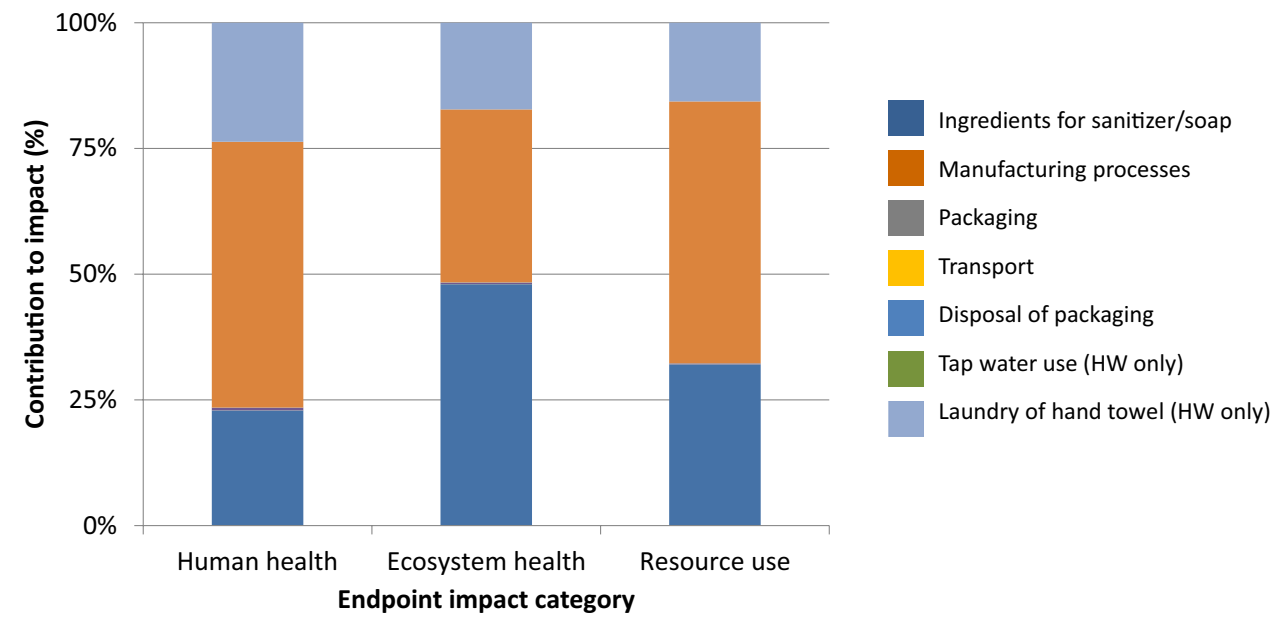

\section{DALYs}

The results of the DALY impact calculations are shown in Fig. 7. The functional unit was the entire UK population practising hand hygiene for 1 year: when adjusted to per person DALY, this impact was equivalent to $114 \mathrm{~h}$ for liquid soap HW, compared to $43 \mathrm{~h}$ for bar soap HW, $41 \mathrm{~h}$ for ethanol-based HS and just $16 \mathrm{~h}$ for the isopropanol-based HS. 
Fig. 7 DALY contributions for each type of hand hygiene

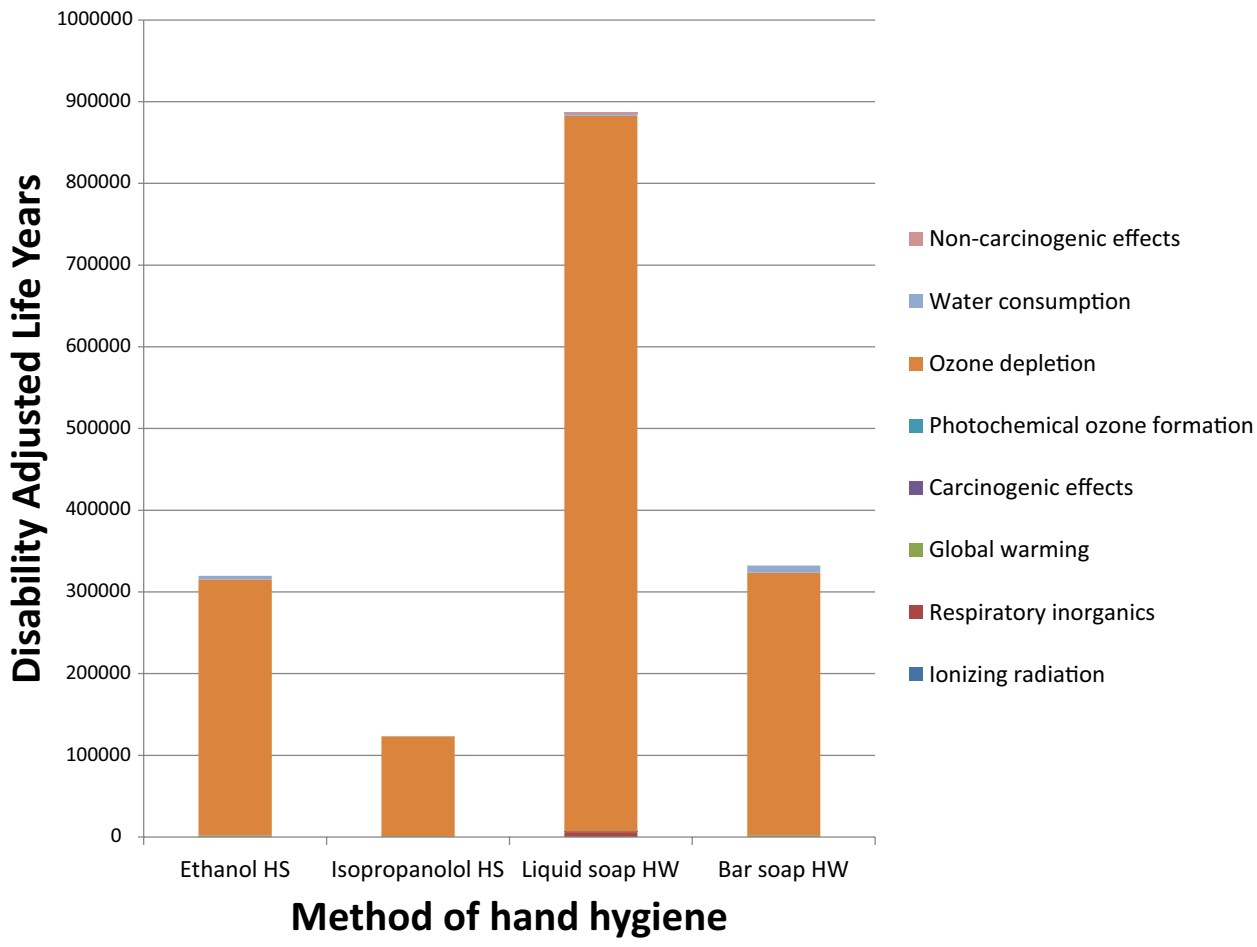

The biggest contributor to the DALY impact for all methods of hand hygiene was ozone depletion (contributing 97-99\% of the total DALY impact).

\section{Discussion}

Hoekman et al. (2018) provides a recent review of the environmental concerns associated with hand sanitiser. Our paper has developed this concept further by performing a Life Cycle Assessment of different methods of hand hygiene with santizer and soap. Our results demonstrate that, from an environmental perspective, there is a clear advantage of using isopropanol-based HS instead of other methods, such as ethanol-based HS and HW with liquid or bar soap. From a climate change perspective, the impact of ethanol-based sanitizer was 1.38 times greater than isopropanol sanitizer, the impact of bar soap was 2.2 times greater, and the impact of liquid soap was 4 times greater. In fact, isopropanol HS performed better than the other methods of hand hygiene in 14 out of the 16 measures of sustainability. It was only outperformed in fossil use and photochemical ozone formation.

The overall human health impact was measured using DALYs. The biggest contributor to the DALY impact, for all methods of hand hygiene, was ozone depletion, which damages the protective ozone layer surrounding our planet. The next highest contributor was for the use of water in each product. Water was required at different stages of the pathway. The first was in packaging and manufacture, water is required to grow and convert the fruit for the ethanol gel, manufacture the isopropanol and also to mould the plastic associated with the packaging. It is also required to manufacture the soap. It is not possible to eliminate water from the manufacturing process, however it may be possible for industry to consider more sustainable packaging which doesn't have such a need for this high water consumption. The other major use of water was in the actual handwashing process. For HW with any type of soap, water is used to wash hands, and undertake laundry processes. Water is also required to treat the waste water that is produced from this process. This is discussed further below.

There is some evidence that one type of HS might be more clinically effective than another. One study showed that $80 \%$ ethanol HS, was more effective than isopropanol (Hübner et al. 2006). Another clinical study showed that ethanol based disinfectant had reduced effectiveness compared to antiseptic handwashing in saline (Hoekman et al. 2018). The type of debris on the hands might also be a factor in the effectiveness of both products. Neither of the soaps used in this study were antiseptic, as WHO and CDC guidelines do not recommend antiseptic hand washing for population level use.

Neither of these studies examined clinical effectiveness against COVID-19 transmission, and so, this discussion will focus on the environmental impact of the four hand hygiene methods. 


\section{Soap}

The use of soap is an important part of hand hygiene with one study showing handwashing with water alone reduced the presence of bacteria to $23 \%(p<0.001)$ but using additional plain soap and water reduced the presence of bacteria to a lower $8 \%$ (comparison of both handwashing arms: $p<0.001$ ) (Burton et al. 2011). The benefit of washing with soap was also confirmed in a study by Luby et al. (2011) where there was a marginal but statistically significant difference between bacterial counts using soap and not using soap.

The CDC recommends either bar soap or liquid soap (Centre for Disease Control Prevention 2020). Within the Ecoinvent database only one category of soap exists, and this was used to model both liquid and bar soap. Therefore, this paper then only looks at the differences in weights of the actual soap, and the reduced packaging needed for bar soap compared with liquid soap.

The LCA for liquid soap showed that the soap oils (palm oil, cottonseed oil, soybean oil, coconut oil) had a contribution of between $24 \%$ (toward the ionizing radiation impact) and $93.60 \%$ (towards the freshwater eutrophication aspect) of the environmental footprint. Freshwater eutrophication impact arises from a number of sources, including growing the oils to produce the soap (e.g. the growing and processing of palm oil) as well as water required to manufacture the soap. It is acknowledged that there is wide variability within the constituents of soap. We know that palm oil is associated with high negative impacts on the environment, but there is no evidence to suggest alternatives would be any better (Standard 2020). Palm oil has been blamed for deforestation, peatland draining and burning in SE Asia, but there is been little research into the impact and trade-off of other comparable product.(Meijaard et al. 2020) In essence if the planet needs to grow the product, it will have some environmental implications, more research is needed to be able to produce soap whilst lowering these factors.

For both liquid and bar soap, the process of handwashing requires using tap water (tap water use contributed $28 \%$ ). There are a number of ways to reduce this footprint. Washing your hands for less time, or with less soap (halving the pump volume reduced LCIA results by of $31 \%$ ) would be one factor, but might also reduce the effectiveness of the process. The NHS (2019) suggests you should use room temperature tap water for an average of $40 \mathrm{~s}$ (NHS, 2019) with a UK tap using 51 of water per minute (DEFRA 2015a, b). This is different from the advice of the CDC which suggests you should wash your hands for at least $20 \mathrm{~s}$. The evidence for how much time you should be spending washing your hands is poor. There are a limited number of studies, with one problem being that simply reducing bacteria doesn't necessarily equate to better hand hygiene or personal health (Luby et al. 2007). The amount of time depends on the type and quantity of debris/pathogen on the hands, but there is evidence to suggest that $15-30 \mathrm{~s}$ is more beneficial for pathogen removal than washing for a shorter time period (Fuls et al. 2008; Jensen et al. 2015). There is also no evidence to suggest the temperature of the water is relevant when it comes to reduction in pathogens in HW (Michaels et al. 2002; Laestadius and Dimberg 2005; Carrico et al. 2013).

The laundry of the hand towel contributed an average of $10.17 \%$ for liquid soap and $17.92 \%$ for hand soap. If the consumer used a smaller hand towel, or washed their towels weekly instead of every second day, this contribution would lower. The Ecoinvent dataset for laundry includes the cleaning, drying and ironing of laundry therefore removing the machine drying and ironing of your towels could also reduce the overall environmental impact (Benjamen 2020).

Our study reinforces the environmental benefits of using bar soap compared with liquid soap. This is for a number of reasons including less plastic packaging with the latter, but also as less soap is released when using a bar. It is unsure as to whether this reduction in soap may also reduce pathogenic efficacy of the bar.

\section{Hand sanitizer}

Rubbing most commercial hand sanitizers on one's hands for as little as $15 \mathrm{~s}$ reduces the amount of many viruses by a factor of 1000 and reduces the amount of a wide range of bacteria by 100,000 (Golin et al. 2020). HS can contain either isopropanol or ethanol. From an environmental perspective, the ethanol within the hand sanitiser is known to be toxic(Von Blottnitz and Curran 2007). Evaporation of ethanol, causes environmental problems, such as increased ethanol found in surface and ground water and a change in photochemical ozone concentration, and the resultant summer smog has been shown with bioethanol fuel. (Jacobson 2007). Isopropanol spills are less problematic, as it breaks down rapidly into organic compounds, but as Mahmood et al. (2020) explains, the substance will still deplete oxygen in a water body.

Within the impact analysis, isopropanol performed better across nearly all measurements compared with ethanol, except for fossil fuel use (isopropanol is made from fossil fuels, whereas the ethanol in this study was made via fermentation). When the results were normalised, fossil fuel use was found to be the least important of the 16 impact categories measured in this LCA (the normalised results for fossil fuel use was 0 for all products). The fact that the impact of ethanol via fermentation was worse for the environment than a fossil fuel based isopropanol is not as surprising as it seems, and is in line with fuel studies showing the problems with using ethanol as a fossil fuel substitute. Northern American studies are mostly based on ethanol produced from corn. A mono-culture crop such as corn can 
inevitably reduce plant and animal biodiversity, and contribute to erosion, nutrient run off and other adverse environmental impacts. Corn ethanol production uses a modest amount of water which can be a significant resource problem where there are constraints of water (Hoekman et al. 2018; Hoekman and Broch 2018, United States 2020). The LCA process draws on a British ethanol which is produced mostly from maize, sugar cane and rye (Ecoinvent dataset v3.7). Each of these require significant planetary resources to grow the product with less resource required to convert the product into the hand gel. The impacts of sugar cane (of which a significant portion of bioethanol are derived) have been recently reviewed and are similar to those of corn (El Chami et al. 2020).

Using less hand sanitizer would reduce its environmental impact but potentially also reduce its ability to disinfect effectively. Zingg et al (2016) found that $3 \mathrm{ml}$ of HS was not always enough to disinfect larger hand sizes and thoroughly cover both sides of the hands before drying.

In this study, hand sanitizer was in general more environmentally sustainable than handwashing with liquid soap, most likely because handwashing with soap and water involves water use and drying the hands with a hand towel, which hand gels do not.

\section{Conclusion}

Hand hygiene is recommended by WHO, CDC, and NHS England to prevent the spread of COVID-19. Hand hygiene using hand sanitizer or soap and water all have an environmental impact, hand sanitizer was more environmentally sustainable than handwashing with soap. Although hand hygiene is a substantial tool in the public health armamentarium, it does cause significant planetary harm. More research is needed to create hand gels which are more environmentally friendly.

Supplementary Information The online version contains supplementary material available at https://doi.org/10.1007/s11356-022-18918-4.

\section{Acknowledgements Not applicable}

Author contribution BD wrote the introduction, and discussion of the paper.

JP gathered the raw data, with help from BD and AL.

AL, with BD inputted the raw data into LCA software and created the results.

PA helped write the introduction and discussion.

AP provided input on the evaporation of ethanol and isopropanol and added to the results and discussion on the relevance of this paper. All authors read and approved the final manuscript.

Funding Open Access funding provided by the IReL Consortium.
Data availability The datasets generated and/or analysed during the current study are available in the tables in the document. The raw material inputted is shown in Appendix B.

\section{Declarations}

Ethics approval Not applicable.

Consent to participate Not applicable.

Consent for publication Not applicable.

Competing interests The authors declare no competing interests.

Open Access This article is licensed under a Creative Commons Attribution 4.0 International License, which permits use, sharing, adaptation, distribution and reproduction in any medium or format, as long as you give appropriate credit to the original author(s) and the source, provide a link to the Creative Commons licence, and indicate if changes were made. The images or other third party material in this article are included in the article's Creative Commons licence, unless indicated otherwise in a credit line to the material. If material is not included in the article's Creative Commons licence and your intended use is not permitted by statutory regulation or exceeds the permitted use, you will need to obtain permission directly from the copyright holder. To view a copy of this licence, visit http://creativecommons.org/licenses/by/4.0/.

\section{References}

Brewer C, Streel E (2020) Is Alcohol in Hand Sanitizers Absorbed Through the Skin or Lungs? Implications for Disulfiram Treatment Alcohol Alcohol 55(4):354-356. https://doi.org/10.1093/ alcalc/agaa045

Britannica. Isopropyl Alcohol. https://www.britannica.com/science/ isopropyl-alcohol. Accessed 5 Dec 2020

Burton M, Cobb E, Donachie P, Judah G, Curtis V, Schmidt W (2011) The effect of handwashing with water or soap on bacterial contamination of hands. Int J Environ Res Public Health 8(1):97-104. https://doi.org/10.3390/ijerph8010097

Carrico A, Spoden M, Wallston K, Vandenbergh M (2013) The environmental cost of misinformation: why the recommendation to use elevated temperatures for handwashing is problematicexternal icon. Int J Consum Stud 37(4):433-441

Centre for Disease Control Prevention (2020) Hand Sanitizer Use Out and About. https://www.cdc.gov/handwashing/hand-sanitizer-use. html. Accessed 5 Dec 2020

Charumilind S, Craven M, Lamb J, Sabow A, Wilson M (2020) When will the Covid 19 Pandemic end. Available at: https://www.mckin sey.com/industries/healthcare-systems-and-services/our-insights/ when-will-the-covid-19-pandemic-end\#. Accessed 4 Dec 2020

Chilton G (2004) How to Get Cleaner Clothes by Weighing Them First .Cleaning and Stain Removal for Dummies. Available at: https:// www.dummies.com/home-garden/home-improvement/cleaningstain-removal/how-to-get-cleaner-clothes-by-weighing-themfirst/. Accessed 5 Dec 2020

DALYS (2020) Interpretation of metrics: DALYs and damage to human health. Available at: https://pre-sustainability.com/articles/metri cs-interpretation-daly-and-damage-to-human-health/. Accessed 4 Dec 2020

DEFRA (2015a) 'Water-efficient taps Mandatory level'. https://assets. publishing.service.gov.uk/government/uploads/system/uploads/ 
attachment_data/file/482120/gbs-taps-automatic-sprays-showe rs-urinal-2015.pdf. Accessed 5 Dec 2020

DEFRA (2015b) Department of Education, Fishing and Agriculture. Government Buying Standards for showers, taps, toilets and urinals. https://assets.publishing.service.gov.uk/government/uploa ds/system/uploads/attachment_data/file/482120/gbs-taps-autom atic-sprays-showers-urinal-2015.pdf. Accessed 5 Dec 2020

DOHSC (2020) Department of Health and Social Care. Available at: https://www.gov.uk/government/news/public-informationcampaign-focuses-on-handwashing. Accessed 5 Dec 2020

Ecoivent (2020). https://www.ecoinvent.org/. Accessed 5 Dec 2020

El Chami D, Daccache A, El Moujabber M (2020) What are the impacts of sugarcane production on ecosystem services and human well-being? Rev Ann Agri Sci 65(2):188-199

ECDPC (2020) European Centre for Disease Prevention and Control. Available at: https://www.ecdc.europa.eu/en/geographical-distr ibution-2019-ncov-cases. Accessed 5 Dec 2020

European Commission Joint Research Centre (2018) Product Environmental Footprint Category Rules Guidance, Version 6.3. Available at. https://eplca.jrc.ec.europa.eu/permalink/PEFCR_guidance_v6. 3-2.pdf. Accessed Nov 2019

Fuls J, Rodgers N, Fischler G, Howard J, Patel M, Weidner P, Duran M (2008) Alternative hand contamination technique to compare the activities of antimicrobial and nonantimicrobial soaps under different test conditions.external icon Appl Environ Microbiol. 74:12;3739-44

Golin AP, Choi D, Ghahary A (2020) Hand sanitizers: A review of ingredients, mechanisms of action, modes of delivery, and efficacy against coronaviruses. Am J Infect Control 48:1062-1067

Hamner R (2020) Just Plain Soap. Available at: https://www.needs. com/product/EWC09-PER-04/a_General_Health. Accessed 5 Dec 2020

Hoekman S, Broch A (2018) Environmental implications of higher ethanol production and use in the U.S.: A literature review. Part II - Biodiversity, land use change, GHG emissions, and sustainability. Renew Sustain Energy Rev 81:2;3159-3177

Hoekman S, Broch A, Liu X (2018) Review Environmental implications of higher ethanol production and use in the U.S.: A literature review. Part I - Impacts on water, soil, and air quality. Renew Sustain Energy Rev 81(3):3140-3158. https://doi.org/10.1016/j. rser.2017.05.050

Hübner N, Kampf G, Löffler H, Kramer A (2006) Effect of a 1 min hand wash on the bactericidal efficacy of consecutive surgical hand disinfection with standard alcohols and on skin hydration. Int J Hyg Environ Health 209(3):285-291. https://doi.org/10.1016/j. ijheh.2006.01.002

ISO (2015) International Organization for Standardization. ISO 14001:2015 - Environmental management systems - Requirements with guidance for use. 2015. https://www.iso.org/standard/ 60857.html. Accessed Nov 2019

Jacobson M (2007) Effects of Ethanol (E85) versus Gasoline Vehicles on Cancer and Mortality in the United States. Environ Sci Technol 41(11):4151

Jia L, Xu YF, Shi YZ (2012) Investigation of the Ozone Formation Potential for Ethanol using a Smog Chamber Chin Sci Bull 57(34):4479-81

Jensen J, Danyluk M, Harris L, Schaffner D (2015) Quantifying the effect of hand wash duration, soap use, ground beef debris, and drying methods on the removal of Enterobacter aerogenes on handsexternal icon. J Food Prot 78(4):685-690

Joseph T, Baah K, Jahanfar A, Dubey B (2015) A comparative life cycle assessment of conventional hand dryer and roll paper towel as hand drying methods. Sci Total Environ. 15:5;515-516:109_ 17. https://doi.org/10.1016/j.scitotenv.2015.01.112

Kratzel A, Todt D, V'kovski P, Steiner S, Gultom M, Thao T, Ebertm N, Holwerda M, Steinmann J, Niemeyer D, Dijkman R, Kampf
G, Drosten C, Steinmann E, Thiel V, Pfaender S (2020) Inactivation of Severe Acute Respiratory Syndrome Coronavirus 2 by WHO-Recommended Hand Rub Formulations and Alcohols. Emerg Infect Dis 26(7):1592-1595. https://doi.org/10.3201/eid26 07.200915

Laestadius J, Dimberg L (2005) Hot water for handwashing-where is the proof? J Occup Environ Med 47(4):434-435

Luby S, Agboatwalla M, Billhimer W, Hoekstra R. (2007). Field trial of a low cost method to evaluate hand cleanliness.external icon Trop Med Int Health. 12(6)765-71

Luby S, Halder A, Huda T, Unicomb L, Johnston R (2011) The effect of handwashing at recommended times with water alone and with soap on child diarrhea in rural Bangladesh: an observational study. PLoS Med 8:6. https://doi.org/10.1371/journal.pmed.1001052

Mahmood A, Eqan M, Pervez S et al (2020) COVID-19 and frequent use of hand sanitizers; human health and environmental hazards by exposure pathways. Sci Total Environ 742. https://doi.org/10. 1016/j.scitotenv.2020140561

McGill (2020) Office for Science and Society. Liquid or bar? Soapy tales. (2020) Available at: https://www.mcgill.ca/oss/article/ health/liquid-or-bar-soapy-tales. Accessed 4 Dec 2020

Meijaard E, Brooks T, Carlson K et al (2020) The environmental impacts of palm oil in context. Nat Plants 6:1418-1426. https:// doi.org/10.1038/s41477-020-00813-w

Michaels B, Gangar V, Schultz A, Arenas M, Curiale M, Ayers T, Paulson D (2002) Water temperature as a factor in handwashing efficacy. Food Service Technology 2:139-149

NLM (2021) National Library of Medicine. Available at: https://pubch em.ncbi.nlm.nih.gov/compound/Isopropyl-alcohol

New York Times (2020) Coronavirus Has Caused a Hand Sanitizer Shortage. What Should You Do? Available at: https://www.nytim es.com/2020/03/11/smarter-living/wirecutter/coronavirus-handsanitizer.html. Accessed 5 Dec 2020

NHS England (2019) Best way to wash your hands. Available at: https://www.nhs.uk/live-well/healthy-body/ best-way-to-wash-your-hands/

Office for national statistics (2020) People, population and community. Available at: https://www.ons.gov.uk/peoplepopulatio nandcommunity/populationandmigration/populationestimates. Accessed 4 Dec 2020

OpenLCA. https://www.openlca.org/. Accessed 5 Dec 2020

Pinhas A (2010) A Kinetic Study Using Evaporation of Different Types of Hand-Rub Sanitizers. J Chem Educ 87(9):950-951. https://doi. org/10.1021/ed1003492

ReCiPe (2016) https://pre-sustainability.com/articles/recipe/. Accessed 5 Dec 2020

Richter (2016) Saving time and money with Gojo. https://www.richt eronline.com/saving-time-and-money-with-gojo/. Accessed 5 Dec 2020

Sickbert-Bennett E, Weber D, Gergen-Teague M, Sobsey M, Samsa G, Rutala W (2005) Comparative efficacy of hand hygiene agents in the reduction of bacteria and viruses. Am J Infect Control 33(2):67-77. https://doi.org/10.1016/j.ajic.2004.08.005

Standard (2020) Best palm oil free soaps. Available at: https://www. standard.co.uk/shopping/esbest/beauty/skincare/best-palm-oilfree-soaps-a4190841.html (Accessed Dec 04th 2020). (Accessed Dec 05, 2020)

Statistica (2021) Average household size in Great Britain. https://www. statista.com/statistics/525489/average-household-size-in-greatbritain/\#: :text=It/20can/20be/20seen/20that,to/202.4/20people/ 20per/20household

Sturt (2015) How Often You Should Actually Be Washing Your Towels And Sheets. https://www.huffpost.com/entry/how-oftenyou-should-actually-be-washing-your-sheets_n_55cb9271e4 b0f1cbf1e72931\#: :text=during/20holiday/20seasons./E2/80/ 
9D-,Hand/20towels, more/20frequently/20than/20most/20linens. Accessed 5 Dec 2020

United States (2020) Environment Protection Agency. Biofuels and the Environment: the First Triennial Report To Congress (2011 Final Report). Available at: https://cfpub.epa.gov/ncea/biofuels/recor display.cfm?deid=235881. Accessed 4 Dec 2020

Von Blottnitz H and Curran M (2007) A review of assessments conducted on bio-ethanol as a transportation fuel from a net energy, greenhouse gas, and environmental life cycle perspective. https:// doi.org/10.1016/j.jclepro.2006.03.002

Whitmee S, Haines A, Beyrer C (2015) Safeguarding human health in the Anthropocene epoch: report of The Rockefeller FoundationLancet Commission on planetary health. Lancet 2015; published online July 16. https://doi.org/10.1016/S0140-6736(15).60901-1

WHO (2019) World Health Organization. Novel Corona Virus 2019. https://www.who.int/emergencies/diseases/novel-coronavirus2019/situation-reports. Accessed 5 Jan 2020

WHO (2020a) World Health Organisation. Save lives in the context of Covid. Available at: https://www.who.int/docs/default-source/ coronaviruse/who-hh-community-campaign-finalv3.pdf?sfvrsn= 5f3731ef_2\&download=true. Accessed 5 Dec 2020

WHO (2020b) World Health Organisation. Section 12.1.1. Suggested composition of alcohol-based handrub formulations for local production. https://www.ncbi.nlm.nih.gov/books/NBK144054/. Accessed 5 Dec 2020
WHO (2020c) World Health Organisation. Hand Hygiene: Why, How \& When? Available at: https://www.who.int/gpsc/5may/Hand Hygiene_Why_How_and_When_Brochure.pdf. Accessed 5 Dec 2020

WHO (2020d) World Health Organization .WHO guidelines on hand hygiene in health care: first global patient safety challenge clean care is safer care. Geneva: the Organization. https://apps.who. int/iris/bitstream/handle/10665/44102/9789241597906_eng.pdf. Accessed 5 Dec 2020

WHO (2020e) World Health Organisation. WHO Director-General's opening remarks at the media briefing on COVID-19 - 11 March 2020. https://www.who.int/director-general/speeches/detail/whodirector-general-s-opening-remarks-at-the-media-briefing-oncovid-19---11-march-2020. Accessed 5 Dec 2020

Yang S (2007) Bioprocessing for value-added products from renewable resources: new technologies and applications. Amsterdam, Elsevier. http://public.eblib.com/choice/publicfullrecord.aspx?p= 281975. Accessed 5 Dec 2020

Zingg W, Haidegger T, Pittet D (2016) Hand coverage by alcohol-based handrub varies: Volume and hand size matter. Am J Infect Control 12:1689-1691. https://doi.org/10.1016/j.ajic.2016.07.006

Publisher's note Springer Nature remains neutral with regard to jurisdictional claims in published maps and institutional affiliations. 